\title{
Ellen's Anorexia in To the Bone Movie (2017)
}

\author{
Elsa Lubianti ${ }^{1}$, Mia Fitria Agustina ${ }^{2}$, Shofi Mahmudah Budi Utami ${ }^{3}$ \\ English Literature, Jenderal Soedirman University

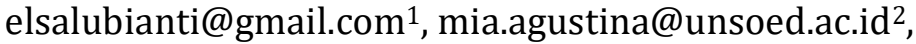 \\ shofi.mahmudah.budi.utami@unsoed.ac.id ${ }^{3}$
}

\begin{abstract}
Article History: Abstract. The research aims to figure out factors causing Ellen, the
First Received: main character of Noxon's movie entitled To the Bone, experiences $28 / 03 / 2020$ anorexia. The qualitative method is used to collect, interpret, and analyze data. Reading, rereading, collecting, sorting, grouping,

Final Revision: $27 / 06 / 2020$ interpreting, and analyzing are steps conducted to get the primary data taken from the movie. In addition, the researcher applied Psychology of Literature Theory, Anorexia Nervosa Theory, and

Available online: Cinematography Theory to answer the research question. The result $30 / 06 / 2020$ of this research shows that Ellen's anorexia is caused by two factors. The first is internal factors (being stress, feeling lonely, and experiencing depression). This factor cannot be seen from other's viewpoints, but it can be felt by Ellen only. The second is external factors because of her parents' divorce. The divorce makes Ellen lack of affection and attention. This divorce also causes poor communication between Ellen and her parents. Thus, those two internal factors lead Ellen feels isolated and also makes Ellen's selfesteem suffered which finally render Ellen experiences anorexia.
\end{abstract}

Keywords: To the Bone, Psychology of Literature, Anorexia Nervosa, Cinematography

\section{http://jos.unsoed.ac.id/index.php/jes}

\section{INTRODUCTION}

Anorexia is a poor eating habit caused by an abnormal fear of being fat. The number of anorexia sufferer has increased in the last 50 years. It is estimated by Academy for Eating Disorder (2006) that in the U.S, 500.000 women were diagnosed anorexia. The number of anorexia increases in some other countries every year, and generally, the sufferer of anorexia are young women. Hence, National Institute of Mental Health (2016), argues that (?) many eating disorders happen to young women rather than men because women are more concerned with their body shape and appearance than men do.

The issue of anorexia is also depicted in movies. One of them is To the Bone (2017), which is an American drama movie written and directed by Martin Noxon. This movie is about a 20-year-old college dropout student named Ellen Kaysen who battles with her anorexia. The factors of anorexic issue depicted in the movie are kind of different. Most people suffer from anorexia is caused by some factors, such as beauty image, body image disturbance, the influence of some friends, mass media, and less confident. 
Meanwhile, in To the Bone movie, Ellen's anorexia is caused by different reasons. Ellen does not want to have a body like a model. She does not get influences from her friends or media to have a thin body. This causes finding the reasons why Ellen experiences anorexia is something challenging to be done.

To find Ellen's reasons of anorexia, theories are needed, for example, the psychology of literature, anorexia nervosa theory, and cinematography theory. Based on American Psychological Association (APA) (in Christian Norqvist, 2018), "Psychology is the study of the mind and behaviour. It is the study of the mind, how it works and how it affects behavior." in literature studies, Wellek and Warren (1949:75) mention four focuses of study which are the psychological study of the writer, as type and as individual, or the study of the creative process, or the study of the psychological types and laws present within works of literature, or, finally, the effects of literature upon its readers (audience psychology). Based on those four, this research applies study on the psychological types and laws presents within works of literature. The chosen study is because anorexia is a kind of eating disorder in which National Institute of Mental Health (NIMH, 2016) describes as "...serious and often fatal illnesses that are associated with severe disturbances in people's eating behaviors and related thoughts and emotions". Anorextic may be caused by internal factors such as having negative body image, being less confident, stress, experiencing loneliness, depression, being perfectionist, impulsive, having difficulty managing emotion, and other psychology factors. Meanwhile, the external factor is sociocultural factors such as the influence of some friends, bullying, physical abuse, sexual abuse, and media abuse. Therefore, it can be related that this research needs psychology of literature as anorexia may have a relation with mid diseases.

Related to cinematography, Rodrigo Prieto (in Tersigni A, 2017) says that, "we are telling emotional stories with the images; it's not just making beautiful pictures. I think that is a big misconception. People think "it's good cinematography because it's beautiful". There are five main points of filming techniques, according to Maschelli (1998), namely camera angles, continuity, cutting (editing), close ups, composition. This theory becomes important because the object of the research is in the form movie. The theory of the movie helps to get support data to get the answer to the research question.

\section{RESEARCH METHOD}

This research uses a qualitative method since, in the science of sociology, anthropology, and psychology, the qualitative research method focuses on explanations and descriptions (Hakim as cited in UKEssays Article, 2000). A qualitative study is defined as an inquiry process of understanding a social or human problem. This kind of research is conducted in order to find a complex and holistic picture of the problems.

The data for this article are taken from To the Bone drama movie by Martin Noxon. It is also supported by the data from articles, books, essays, dialogs, journals, online research and other sources relevant to Ellen's anorexia as seen in To the Bone movie directed by Martin Noxon.

In collecting the data, there are several steps to do: watching and re-watching the movie, collecting the data from the movie, collecting the data from supporting 
documents, and reducing the data. After the data are collected, the next steps are classifying the data, validating the data, analyzing the data, and concluding the data.

\section{RESULT AND DISCUSSION}

To answer the research question, the discussion of this research is divided into two parts, the external factors and the internal ones. The anorexia experienced by Ellen is not because she wants to be slim. She does not want to be a supermodel either. In the movie, these reasons cannot be found. What is presented is how Ellen attempts to get the attention of her parents through starving herself. It is unconscious that can be divided into internal factors (being stress, feeling lonely, and experiencing depression) and external factor about her parents' divorce.

\section{INTERNAL FACTORS}

Internal factors that cause anorexia, according to the National Eating Disorders Association (2018), are because of body image disturbance, less confident, stressful, loneliness, depression, perfectionism, and difficulty managing emotions. Related to To the Bone, Ellen, the main character of the movie also experiences internal factors causing her to be an anorexic such as being stress, feeling lonely, and experiencing depression.

\section{Stress}

The most dangerous thing about stress is how easily it can creep up on people. It is important to be aware of some. Symptoms of stress including cognitive symptoms, namely memory problem, inability to concentrate, poor judgment, negative thoughts, anxious or racing thoughts, constant worrying; physical symptoms like aches and pains, diarrhea or constipation, dizziness, chest pain, and rapid heart rate; emotional symptoms such as general unhappiness, anxiety, moodiness, anger, irritability, feeling overwhelmed and other emotional health problems; and behavioral symptoms namely eating more or less, too much or less sleeping, using alcohol, cigarettes, or drugs to relax, neglecting responsibilities, and nails biting habits (Segal J et al., 2019).

In To the Bone movie, Ellen's stress is seen through some symptoms; cognitive symptoms such as negative thoughts and constant worrying, emotional symptoms like anxious, and behavioral symptoms, namely less sleeping, smoking cigarettes, and nails bitting habits. All those symptoms that she experienced, limit her intake of daily food, which makes her deficient in nutrients; and leads her to become an anorexic.

Some symptoms that indicate Ellen's stress are negative thoughts (as it is shown in the way Ellen thought that her family ignored her) in scene 00:54:25, constant worrying (of her body image) in 00:14:34, inability to control herself shown in 00:47:57, and insomnia (in which she used to draw foods to distract her hunger) as it is shown in 00:48:33. Some other symptoms are shown in her smoking and her nail-biting behaviors.

In (00:44:06), Ellen smokes again when she was in a bad mood. The day after Ellen had done family therapy did not result in anything that could help her to recover from anorexia. Ellen leaves her dinner and goes to the backyard smoking alone. It is shown that to relax her mind, she smoked. Some people who are stressed or under pressure will usually smoke to relax their mind but actually smoking can 
make them feel stress more. According to Dr. Rachel (2016), when people smoke, nicotine stimulates people's brains to release dopamine, which is a chemical associated with pleasurable feelings. As smokers, people need more levels of nicotine to stimulate dopamine to feel "normal". When the nicotine level in people's blood drops, people begin to crave a cigarette which makes people feel stressed until that craving is satisfied. The relief people feel is satisfying people's craving. This is the feeling that people are mistaking as "relaxing". Unfortunately, the toxins and nicotine in cigarettes have the completely opposite effect on people's bodies.

The last symptom is nail-biting behavior. The psychological factors associated with this behavior are stress, anxiety, anxiety, and less of a good mood (cited in "guesehat, 2018). In (00:02:32), while she is looking out the restaurant, Ellen showed her interest in food. It was seen when she looked at the restaurant while biting her finger. This scene shows that she wants to eat. She is craving for food, but her brain orders her not to eat. It is also shown in (00:02:36). The closeups of the movie zoomed-in Ellen pleats her hand on the chest. It is like Ellen imagining the food at the restaurant from a distance.

Meanwhile, someone who pleats their hand on the chest is not only interpreted as someone who is angry but also can be interpreted as someone who is thinking or observing something (Circa, 2018). It aims to restrain her mind from food because Ellen should maintain her weight by avoiding high-calorie food. Thus, Ellen shows the symptom of stress by biting her nails and her symptoms of anorexia.

\section{Loneliness}

Loneliness is another cause of Ellen's anorexia. Her loneliness is seen through two symptoms which include the inability to connect with others or to withdraw from others and having no close friend. These affect Ellen physically. It makes her constantly lose weight because she lacked interest in food. Besides, Ellen's loneliness also caused by the fact that she lost her loved ones, her parents.

At first, Ellen's loneliness symptoms shown when she is unable to connect with others or withdrawing from others. It is seen in 00:01:19- 00:01:39. Ellen's friend is talking about food, especially chocolate, but Ellen gives a rude response.

Ellen's friend: What about the chocolate cake? It's like they're trying to drive us crazy.

Ellen: "Society's to blame. The world is so unfair. I have to die. "There's no point in blaming everybody. Live with it".

Ellen's teacher: Ellen, do you think there's a way you can express that without discounting Penny's feelings?

After that, Ellen continues to give a rude remark with a vulgar slang, which is written in the board that reads "suck my skinny balls".

In this movie, Ellen does not show that she needs a man to help her solve her problem. It shows that she does not want to have a close relationship with anyone. In fact, throughout this movie, Ellen does not realize that she does receive support from other characters such as her sister, her biological mother, Luke, her stepmother, and her father which demonstrate the incredible power of families or loved ones in treatment. Instead, she decides to face everything by herself. For instance, as shown in (00:08:57), Ellen confronts her life's problem without telling 
anyone. Ellen tells her sister that she can solve her eating disorders problem in her own way. Sadly, she cannot solve the problem by herself. Instead, by doing everything alone, she even feels lonelier, and this loneliness causes her anorexia to worsen. "When a feeling of being alone and disconnected persists for extended periods, persistent loneliness can lead because of a lack of interest in food (cited in "crisis text line: loneliness", 2013). Ellen always feels on her own. She never gets accompany by her parents as they busy with their own lives. Her father got married and has her own family. He is also busy with his work and does not have time to be with Ellen. Her mother turns to be a lesbian and has a partner of life that make her has a small portion attention for Ellen. This renders Ellen to feel so lonely. She struggles this for so long, causing her to refuse to eat in crying for attention. "There are so many reasons people could be feeling lonely. These events happened in people's life recently; physical and mental health is poor, lost a friend, a family or loved one" (cited in "crisis text line: loneliness", 2013).

\section{Depression}

Depression is the third internal factor. According to Smith and Segal (2019), there are some common symptoms of depression, such as feeling of hopelessness and helplessness, anger or irritability, loss of interest in daily activities, sleep changes, appetite, or weight changes, self-loathing, concentration problems, unexplained aches and pains. The symptoms of depression can be caused by biological or hormones causes, psychological causes, and social causes (Gregory C, 2019).

In To the Bone movie, some of Ellen's symptoms of depression are hopelessness, anger or irritability, weight changes, and self-loathing. In this movie, Ellen hopes that she survives from her anorexia, but she does not know how. She feels helpless. She is expecting a figure who can help her. She has waited, but no one comes to her "life" to save her. Instead, it is Beck, a doctor who helps Ellen survive from anorexia. Beck told her that there is no point in hoping from others.

Beck: You know how. Stop waiting for life to be easy. Stop hoping for somebody to save you. You don't need another person lying to you. (1:21:41$1: 21: 46)$

The second Ellen's depression symptoms are shown when she was angry or irritable. People who are depressed will be easily upset, disappointed and offended (Anindyaputri, 2016). The case happened when Luke tried to make Ellen eat goo goo cluster.

Luke: How would you eat them? Show me.

Ellen: You wish.

(Time 00:49:05- 00:49:12) Then,

it is continue..

Luke: You know you want it.

Ellen: Shh! I... I can't.

Luke: You can. Chew, swallow. The world will not implode, I swear. Come

on, do it.

Ellen: Okay, seriously, back off!

(Time 00:51:57-00:53:51) 
The third symptom is shown when her weight changes. This indicates that she always eats a small portion of food because she needs to maintain her weight. Ellen: I get all panicky even thinking about it, like, the world is gonna fall apart. Yeah, but aren't you scared. you won't be able to stop?

(Time 00:47:52- 00:48:00)

Here, Ellen showed how much she fears of gaining weight. She wants to eat that goo goo cluster, but her fear is greater than her wishes. She thought that she would not be able to stop eating if she tries even the smallest amount of candy. If she does so, it would mean the end of the world for her.

The last symptom is shown when she is self-loathing. As Gregory (2019) argued, "people who suffer from depression will show some of the symptoms, one of them is from his thoughts that blame themselves. They will be said that it is my fault, I am a failure, I am worthless, people will be better off without me, life is not worth living and nothing good ever happens to me."

Ellen's self-loathing is shown when she feels guilty to one of her Tumblr's fans. In this movie, Ellen likes to draw her body shape. Then, she has one fan who is interested in the picture Ellen posted on Tumblr. She wanted to be like in the picture, so the fan was getting thinner and died. Thus, the parents of the fan sent her a letter and said that her daughter's death was caused by Ellen. Therefore, it makes her thought that she is guilty. This incident burdens Ellen and makes her depressed, but in fact, Ellen does not mean it. The issue is shown below:

Ellen: I didn't mean it. I... I mean, I didn't mean for my drawings to do what they did.

Beck: What?

Ellen: On Tumblr.

Ellen: I know Susan told you what happened, and... it'll come up, I bet.

Beck: Right.

Ellen: I was just doing what all my teachers told me to do.

Beck: Draw what you know?

Ellen: Yeah.

Beck: I hear you. Just keep it for yourself, for now, okay?

Ellen: Okay.

(Time 00:31:10-00:31:43)

\section{EXTERNAL FACTORS}

Anorexia can occur by external factors. In To the Bone movie, the main character, the external factor of Ellen's anorexia is the conflict within her own family. The conflict is seen through the story of the movie. This conflict is mainly because of her parents' divorce that causes it as the first external factor of her anorexia. Ellen who witnesses the divorce is disturbed by the thought of not seeing their parents together again. Children may have a short-term effect of divorce such as anxiety, constant stress, irritability, intense sadness, and disillusion. Meanwhile, Short-term effects of divorce can hamper a child's psychological and physiological growth which can have a long-term impact such as behavioral and social problems, trouble with a relationship, prone to substance abuse, depression, and poor education and socioeconomic position (Garoo, 2019). Since Ellen's parents were separated since she 
was a child, the impact of the divorce influence Ellen deeper. The period of time proves that the effect on her is severe. She is so sad because of the divorce and it is worse as her parents pay only a little attention to her.

Another family conflict that is shown through this movie is the poor communication among Ellen, her stepmother and her biological mother. Since her parents divorced, Ellen and her mother had never made a direct contact with each other. Ellen's mother already gives up on Ellen. Ellen does not speak to her mother either. Rather, she stalks her mother on social media (Facebook) and looks at her mother's photos (00:10:07). This illustrates that Ellen misses her mother and desires her presence especially when she struggles with her anorexia, though in fact they are not close enough. Stalking is the act of following someone or something very closely and watching its every move or in a simple word, stalker is a person who is curious about someone who they stalked and their goal to know his or her life deeper through social media (Flynn, 2018). This quote strengthens that Ellen wants to get connection with her mother even only through social media. It is so sad that a child may only get information of person she loves by media. Ellen does not have time to share what she thinks and what she wants to her mother. She is also eager to know about her mother, yet she may get the information from her mother's Facebook.

Furthermore, Ellen also has a poor communication with her Father. Throughout the movie, Ellen's father is not physically present. He is only occasionally talked by Ellen and her family. After having dinner with her stepsister, Ellen meets her stepmother and then they talk in her mother's room. Her mother tells that her is very upset and worries about Ellen because Ellen has problem at school and she is still struggling with anorexia (00:05:05), His father could not speak directly because he is busy working. This is why Ellen and her father are not very close. Her father always makes excuses when there is a family gathering, and he also never tries to be close with Ellen though he always asks her to be the best.

In addition, poor communication is also shown between Ellen and her stepmother, Susan. At first, their poor communication is shown when Ellen is expelled from her school. Since Ellen lives with Susan, Susan talks to Ellen. She discusses Ellen's rebel and how Ellen turns up to be a bad influence for her friends. Afterward, Susan decides to make a deal with Ellen

(00:05:39). The deal was Ellen could live here as long as she kept up her end of the bargain (00:05:36). If Ellen could not follow the deal then her stepmother would send her to Phoenix and had to stay with her mother. There is no discussion on what Ellen did. Her step mother only concludes things from her own perspectives. She does not open conversation with Ellen to get reasons behind Ellen's attitude. This shows that the relationship between them is not healthy it is poor as the communication is only one sided.

In conclusion, poor communication becomes the external factors of Ellen's problem. This poor communication between Ellen and her parents leads her to be anorexic. Poor family communication can include yelling, holding grudges, keeping secrets, blaming, giving the silent treatment, using ultimatums or threats, labeling someone bad instead of the behavior, and bringing harm. If this happens in long period, poor communication will cause depression as physic and emotion are 
involved. This depression can be severe and leads to mental diseases such as refusing to eat.

\section{CONCLUSION}

Based on the research, it can be concluded that the two factors that caused Ellen's anorexia are internal factors and external factors. These problems happened to Ellen at a young age made her psychological condition be problematic because she still was immature. Ellen then experiences depression because he starts to eat less. This refusal to eat is Ellen's ways to get the attention and affection of her parents. Unfortunately, her parents did not understand and realize it. Therefore, it led her to be anorexic instead.

\section{REFERENCES}

To the Bone Movie. Dir. Martin Noxon. Perf. Lily Collins, Keanu Reeves, Alex Sharp. To the Bone Production. 2017.

Anindyaputri, I. (2016). Perbedaan stress dan depresi. Retrieved from https://hellosehat.com/hidup-sehat/psikologi/kenali-perbedaan-stresdandepresi-sebelum-terlambat/

Flynn, E. (2018). 7 signs youre being facebook stalked. Retrieved from https://www.bustle.com/p/7-signs-youre-being-facebook-stalked-becauseomg-there-are-so-many-clues-9236608

Garoo, R. (2019). 10 negative effects od divorce on children and ways to mitigate them. Retrieved from https://www.momjunction.com/ar ticles/side-effectsdivorced-parents-children_0022338/\#gref

Gregory, C. (2019). Depression in woman. retrieved from https://www.psycom.net/depression.central.women.html

Guesehat. (2018). Menggigit kuku, kebiasaan atau gangguan mental. Retrieved from https://www.guesehat.com/gigit-kuku-kebiasaan-atau-gangguan- mental

Mascelli, Joseph V. (1998). The five C's of cinematography: Motion picture filming techniques. Second Edition, California: Silman James Press.

National Institute of Mental Health. (2016). Eating disorders. Retrieved from https://www.nimh.nih.gov/health/topics/eating-disorders/index.shtml

National Institute of Mental Health. (2018). Eating disorder: About more than food. US: Department of health and human services

Rachel. (2016). Why does smoking a cigarette relax me. Retrieved from https://wgno.com/2016/01/26/why-does-smoking-a-cigarette-relaxmedr- rachel-explains/

Segal, J et al. (2019). Stress symptoms, signs and causes. Retrieved from https://www.helpguide.org/articles/stress/stress-symptoms-signs-and causes.htm

Smith, M. \& Segal J. (2019). Depression symtomps and warning signs. Retrieved from https://www.helpguide.org/articles/depression/depressionsymptomsand-warning-signs.htm

Tersigni, Alessandro. (2017). Award-winning cinematographers explain cinematography. Retrieved from https://www.format.com/magazine/news/photography/what-iscinematography 
9 J-Lalite: Journal of English Studies Vol.1, No.1, June, 2020

UK Esaays. (2016). Definition available for qualitative research given by different author. Retrieved from https://www.ukessays.com/essays/psychology/definitions-availableforquantitative-research-given-by-different-authors-psychology-essay.php

Wellek, R., \& Warren, A. (1949). Theory of Literature. New York: Harcourt, Brace and company. 